\title{
Implementasi Perjanjian Pembiayaan Konsumen di PT. Mitra Dana Top Finance Kota Ternate
}

\author{
Mardia Ibrahim \\ Fakultas Hukum Universitas Khairun.E-mail: mardiaibrahim75@gmail.com
}

\section{Amin Muhammad}

Fakultas Hukum Universitas Khairun. E-mail: aminmuhammadhukum@gmail.com

\begin{abstract}
:
Consumer financing institutions seem to be another alternative for prospective consumers who choose limitations to obtain the desired goods, this will be easier if supported by the fast process of credit applications at the finance company, then offered to use financing services with an effect on the number of financing requests submitted more increasing. This condition is quite promising benefits and potential customers will increase, but an increase in the number of consumers will become a risk, increasing the occurrence of defaults. Rights and Obligations between debtors and creditors have been stated in the agreement clause, this means that the rights and obligations clause have been fulfilled, but the clause made by PT. Mitra Dana Top Finance still has an unbalanced kalausul and is still detrimental to one party, namely the debtor. Defaults experienced by PT. There are still many Top Finance Fund Partners and PT. Mitra Dana Top Finance in terms of executing goods only uses SP. 1, SP. 2, and SP. 3 (power of attorney) to execute the collateral object in the hands of the debtor without using a Fiduciary deed.
\end{abstract}

Keywords: Implementation, Financing Agreement, Consumer

\section{PENDAHULUAN}

Pada dasarnya kontrak berawal dari perbedaan atau ketidaksamaan kepentingan diantara para pihak. Perumusan hubungan kontraktual tersebut pada umumnya senantiasi diawali dengan proses negosiasi di antara para pihak. Perjanjian dan kontrak pula pada umumnya tidak sama sebab tak semua perjanjian adalah kontrak, sedangkan semua kontrak adalah perjanjian, ini berarti bahwa perjanjian itu luas sedangkan kontrak hanya di ruang lingkup bisnis saja. Hukum perjanjian, berlaku suatu asas, yang dinamakan asas konsensualitas. Perkataan ini berasal dari perkataan latin consensus yang berarti sepakat. Asas konsesualitas bukanlah berarti untuk suatu perjanjian disyaratkan adanya kesepakatan, ini sudah semestinya. Suatu perjanjian juga dinamakan persetujuan, berarti dua pihak sudah setuju atau bersepakat mengenal sesuatu hal. Arti asas konsesualitas ialah pada dasarnya perjanjian dan perikatan yang timbul karenanya itu sudah dilahirkan sejak detik tercapainya 
kesepakatan. Dengan perkataan lain, perjanjian itu sudah sah apabila sudah sepakat mengenal hal-hal yang pokok dan tidaklah diperlukan sesuatu yang formalitas. ${ }^{1}$

Kebebasan berkontrak secara emplisit memberikan panduan bahwa dalam berkontrak pihak-pihak diasumsikan mempunyai kedudukan seimbang. Dengan demikian, diharapkan akan muncul kontrak yang adil dan seimbang pula bagi para pihak. Namun demikian dalam praktik masih banyak ditemukan model kontrak standar (kontrak baku) yang cenderung dianggap berat sebelah, tidak seimbang, dan tidak adil. ${ }^{2}$ Asas proporsionalitas dalam kontrak diartikan sebagai asas yang mendasari pertukaran hak dan kewajiban para pihak sesuai proporsi . Proporsionalitas pembagian hak dan kewajiban diwujudkan dalam sebuah proses hubungan kontraktual, baik pada fase prakontraktual, pembentukan maupun pelaksanan kontrak. Asas proporsionalitas tidak mempermasalahkan keseimbangan (kesamaan) hasil, namun lebih menekankan proporsi pembagian hak dan kewajiban diantara para pihak. ${ }^{3}$

Perwujudan keadilan berkontrak ditentukan melalui dua pendekatan. Pertama, pendekatan procedural, pendekatan ini menitikberatkan pada persoalan kebebasan kehendak dalam suatu kontrak. Pendekatan kedua, yaitu pendekatan substantif yang menekan kandungan atau substansif serta pelaksanaan kontrak. Pendekatan substansif perlu diperhatikan adanya kepentingan yang berbeda. ${ }^{4}$ Lembaga pembiayaan hanya dilakukan dalam ruang lingkup bisnis saja, maka dari itu perusahaan-perusahan, bank, non bank, dan lembaga pembiayaan dalam praktiknya banyak membuat kontrak baku yang d imana klausul dalam perjanjian merugikan para debitor.sebab kontrak yang dibuat tidak berlandaskan asas kebebasan berkontrak dan asas proporsionalitas serta tidak dituangkannya keadilan dalam berkontrak.

Selain kontrak yang dibuat oleh kreditor dan debitor disuatu perusahaan-perusahan, bank, non bank untuk lembaga pembiayaan, juga dikenal dengan perjanjian Fidusia, yang merupakan perjanjian tambahan dari perjanjian pokok. suatu perjanjian yang lahir adanya perpindahan dan berakhir/hapusnya bergantung pada perjanjian pokoknya. Perumusan tersebut memang tepat jika tidak dimaknai bahwa kesepakatan tentang jaminan itu lahir sebagai akibat dari lahirnya kesepakatan utang-piutang karena sesungguhnya yang terjadi dalam praktek adalah kesepakatan jaminan itu yang selalu mendahului sebelum kemudian disepakati perjanjian utang piutangnya. ${ }^{5}$

Undang-undang telah mengatur bahwa semua kebendaan milik debitor baik yang sudah ada maupun yang akan ada baik yang bergerak maupun yang tidak bergerak demi hukum menjadi jaminan atas utang-utang debitor, statementtersebut mengandung persangkaan bahwa tidak ada kreditor (piutang) yang tidak mengandung jaminan. Jaminan yang demikian selain terjadi demi hukum, meliputi seluruh harta milik debitur dan berlaku bagi

\footnotetext{
${ }^{1}$ Subekti,1979. Hukum Perjanjian. PT Intermasa.jakarta.hlm.5

2 Agus Yudha Hernoko.. 2010, Hukum Perjanjian Asas Proporsionalitas dalam kontrak komersial, Prenadamedia Group,Jakarta,Hlm.2

${ }^{3}$ Ibid, hlm. 31-32

${ }^{4}$ Ibid, hlm. 87

5 D.Y Wintanto..2015. Hukum Jaminan Fidusia Dalam Perjanjian Pembiayaan Dan Konsumen. Mandar maju. Bandung, hlm. 105
} 
semua kreditur yang pada asasnya memiliki kedudukan yang sama dan oleh karenanya disebut dengan jaminan umum. ${ }^{6}$

Lembaga pembiayaan konsumen seakan-akan menjadi suatu alternatif lain bagi calon konsumen yang memilih keterbatasan untuk memperoleh barang yang di inginkan, hal ini akan semakin mudah apabila didukung cepatnya proses permohonan kredit pada perusahaan pembiayaan, kemudian ditawarkan menggunakan layanan pembiayaan dengan berpengaruh pada jumlah permohonan pembiayaan diajukan semakin meningkat kondisi Ini cukup menjanjikan keuntungannya dan akan semakin bertambah calon konsumennya, akan tetapi peningkatan jumlah konsumen akan menjadi resiko, semakin meningkat terjadinya wanprestasi.

Kenyataan di PT. MDTF Kota Ternate melakukan kegitan usahan sebagai lembaga perusahan pembiayaan ditemukan beberap mlah yang berkainan dngan pelaksanaan perjanjian dengan jaimian fiducia kendaran bermotor tidak lepas dari risiko yaitu konsumen melakukan wanprstasi antara kreditor dan Debitor khusus wanprestasi dalam pembayaran kredit dengan jaminan Fidusia. Hambatan-hambatan yang dihadapi dalam pelaksanaa PT. Mitra Dana Top Finance di kota Ternate, merupakan salah satu dari sekian banyak lembaga pembiayaan kendaraan bermotor di Kota Ternate yang mana, dalam klausul-klausul perjanjian masih merugikan debitur dan dalam hal pelaksaan eksekusi benda yang dijaminkan tidak memakai fidusia dan serta merta menarik barang dengan semena-mena.

Uraian diatas mendorong penulis untuk meneliti di PT. Mitra Dana Top Finance, untuk meneliti lebih jauh bagaimana pelaksanaan eksekusi dari PT. Mitra Dana Top Finance tanpa adanya jaminan Fidusia.

\section{Kajian Kepustakaan}

\section{A. Perjanjian pada umumnya}

Perjanjian berasal dari istilah Belanda yaitu overeenkomst oleh karena itu suatu perjanjian adalah suatu perbuatan dengan mana satu orang atau lebih mengikatkan dirinya kepada satu orang atau lebih lainya ,perjanjian menyiratkan bahwa sesungguhnya dari suatu perjanjian lahirnya suatu kewajiban atau prestasi dari satu orang atau lebih orang atau pihak lain yang berhak atas prestasi. Menurut Subekti, perjanjian adalah suatu peristiwa dimana seseorang berjanji kepada seorang lain atau dimana dua orang itu saling berjanji untuk melaksanakan sesuatu hal. ${ }^{7}$ Wirjono Prodjodikoro, perjanjian adalah suatu perhubungan hukum mengenai harta benda antara dua pihak dalam mana suatu pihak berjanji atau dianggap berjanji untuk melakukan suatu hal atau untuk tidak melakukan sesuatu hal, sedang pihak lain berhak menuntut pelaksanaan janji itu. ${ }^{8}$ R. Setiawan, adalah suatu perbuatan hukum dimana satu orang atau lebih mengikatkan dirinya atau saling mengikatkan dirinya terhadap satu orang atau lebih. ${ }^{9}$

\footnotetext{
${ }^{6}$ Ibid, hlm. 37

${ }^{7}$ Subekti, 1979, Hukum Perjanjian, PT. intermasa. Jakarta. Hlm. 1

${ }^{8}$ www.kostummerdeka.blogspot.com di akses tanggal 29 novermber 2018 pukul 12.00

9 Www.kostummerdeka.blogspot.com di akses tanggal 29 novermber 2018 pukul 12.01
} 
Abdulkadir Muhammad, perjanjian adalah suatu persetujuan dengan dimana satu orang atau lebih mengikatkan diri untuk melakukan suatu hal dalam lapangan harta kekayaan. ${ }^{10}$ Uraian pengertian di atas bahwa telah jelas, perjanjian adalah suatu perbuatan hukum yang disetujui oleh pihak-pihak yang membuat perjanjian tersebut dan bersifat mengikat bagi mereka yang membuat perjanjian. Pendapat para sarjana di atas bahwa rumusan perjanjian yang terdapat dalam pasal 1313 KUHPerdata.

Hal ini berkaitan dengan asas konsesualitas, suatu perjanjian lahir pada detik tercapainya kesepakatan atau persetujuan antara kedua belah pihak mengenai hal-hal yang pokok dari apa yang menjadi objek perjanjian. Sepakat adalah suatu persesuaian paham dan kehendak antara dua pihak tersebut. Apa yang dikehendaki oleh pihak yang satu, adalah juga yang dikehendaki oleh pihak yang lain. Meskipun tidak sejurusan tetapi secara timbal balik. Kedua kehendak itu bertemu satu sama lain. ${ }^{11}$ Lazimnya suatu perjanjian adalah timbal balik atau bilateral. Artinya : suatu pihak yang memperoleh hakhak dari perjanjian itu, juga menerima kewajiban-kewajiban yang merupakan kebalikannya dari hak-hak yang diperolehnya, dan sebaliknya suatu pihak yang memikul kewajiban-kewajiban juga memperoleh hak-hak yang dianggap sebagai kebalikannya kewajiban-kewajiban yang dibebankan kepadanya itu. ${ }^{12}$

Apabila tidak demikian halnya, yaitu apabila pihak yang memperoleh hak-hak dari perjanjian itu tidak dibebani dengan kewajiban-kewajiban sebagai kebalikannya dari hakhak itu, atau apabila pihak yang menerima kewajiban-kewajiban tidak memperoleh hakhak sebagai kebalikannya, maka perjanjian yang demikian itu, adalah Unilateral atau sepihak. ${ }^{13}$ Perjanjian Baku atau Klausula baku adalah suatu kontrak tertulis yang dibuat hanya oleh salah satu pihak dalam kontrak tersebut, bahkan sering kali kontrak tersebut sudah tercetak (boilerplate) dalam bentuk formulir-formulir tertentu oleh salah satu pihak, yang dalam hal ini ketika kontrak tersebut ditandatangani umumnya para pihak hanya mengisikan data-data informatif tertentu saja dengan sedikit atau tanpa perubahan dalam klausula-klausulanya, di mana pihak lain dalam kontrak tersebut tidak mempunyai kesempatan atau hanya sekdikit kesempatan untuk menegosiasi atau mengubah klausulaklausula yang sudah dibuat oleh salah satu pihak tersebut, sehingga biasanya kontrak baku sangat berat sebelah. Pasal 1 butir 10 UUPK ditetapkan bahwa "Klausula baku adalah setiap aturan atau ketentuan dan syarat-syarat yang telah dipersiapkan dan ditetapkan terlebih dahulu secara sepihak oleh pelaku usaha yang dituangkan dalam suatu dokumen atau perjanjian yang mengikat dan wajib dipenuhi oleh konsumen". ${ }^{14}$

Perjanjian yang dibuat dalam bentuk tertulis dan dibuat dalam bentuk akta. Bentuk akta dibagi dalam 2 macam bentuk yaitu :

\footnotetext{
${ }^{10}$ Simanjuntak, 2015, Hukum Perdata Indonesia, PT. Kharisma Putra utama, Jakarta, Hal. 285

${ }^{11}$ Subekti,1979. Hukum Perjanjian. PT Intermasa.jakarta.hlm. 26

${ }^{12}$ Ibid, hlm. 29-30

${ }^{13} \mathrm{Ibid}$, hlm. 30

${ }^{14}$ Celina Tri Siwi Kristiyanti, 2008, Hukum Perlindungan Konsumen. Sinar Grafika. Hlm, 141
} 
a. Akta Autentik

Akta Autentik adalah suatu akta yang bentuknya ditentukan oleh Undang-Undang, dibuat oleh atau dihadapan pejabat umum yang berwenang untuk itu ditempat dimana akta dibuatnya (pasal 1868 KUHPerdata).

Keistimewaan akta Autentik adalah merupakan suatu alat bukti yang sempurna (velledig bewijs tentang apa yang dimuat di dalamnya), artinya apabila seseorang mengajukan akta Autentik kepada hakim sebagai bukti, maka hakim harus menerima dan menganggap apa yang tertulis didalam akta merupakan peristiwa yang sungguhsungguh telah terjadi dan hakim tidak boleh memerintahkan perubahan pembuktian.

Hal suatu perjanjian, apa yang diperjanjikan, dinyatakan dalam akta Autentik itu adalah benar-benar dinyatakan oleh para pihak sebagai dilihat dan didengar oleh notaris terutama benar mengenai tanggal akta, tanda tangan didalam akta, identitas para pihak yang hadir, dan tempat dibuat akta itu, merupaka kekauatan pembuktian formal sedangka kekuatan pembuktian materiil isi atau substansi akta adalah benar.

b. Akta dibawah tangan

Akta dibawah tangan (onderhands acte) adalah akta yang dibuat tidak oleh atau tanpa perantara seorang pejabat umum, melainkan dibuat dan ditanda tangani sendiri oleh para pihak yang mengadakan perjanjian. Dalam hal para pihak yang menandatangani surat perjanjian tersebut mengakui dan tidak menyangkal tandatangannya, tidak menyangkal isi dan apa yang tertulis dalam surat perjanjian tersebut, maka akta dibawah tangan tersebut mempunyai kekuatan pembuktian yang sama dengan suatu akta otentik.

Pasal 1875 KUHPerdata menyatakan bahwa : "Suatu tulisan dibawah tangan yang diakui oleh orang terhadap siapa tulisan itu hendak dipakai, atau yang dengan cara menurut Undang-Undang dianggap sebagai diakui memberikan terhadap orang-orang yang menandatanganinya serta para ahli warisnya dan orang-orang yang mendapat hak dari mereka, bukti yang sempurna seperti suatu akta otentik, dan demikian pula berlakulah ketentuan pasal 1871 untuk tulisan itu, yang dalam ayat (2) berbunyi : jika apa yang termuat disitu sebagai suatu penuturan belakah tidak ada hubungannya langsung dengan pokok isi akta, maka itu hanya dapat berguna sebagai permulaan pembuktian dengan tulisan”.

Berdasarkan uraian diatas maka dapat diketahui perbedaan antar akta Autentik dengan akta dibawah tangan adalah sebagai berikut :

1. Akta Autentik ( pasal 1868 KUHPerdata )

a. Akta otentik dibuat dalam bentuk sesuai dengan yang ditentukan oleh UndangUndang .

b. Harus dibuat oleh atau dihadapan pejabat umum yang berwenang.

c. Mempunyai kekuatan pembuktian yang sempurna, terutama mengenai waktu, tanggal pembuatan dan dasar hukum.

d. Kalau kebenarannya disangkal maka si penyangkal harus membuktikan ketidak benaran.

2. Akta dibawah tangan :

a. Tidak terikat bentuk formal, melainkan bebas. 
b. Dapat dibuat bebas oleh penandatangan atau tidak disangkal, akta tersebut mempunyai kekuatan pembuktian yang sempurna sama halnya seperti akta otentik.

c. Tetapi apabila kebenerannya disangkal, maka pihak yang mengajukan sebgai bukti yang harus membuktikan kebenarannya (dengan menggunakan bukti saksi-saksi yang sudah dewasa untuk memperkuat pembuktian).

Akta dibawah tangan dapat mempunyai kekuatan pembuktian yang sempurna seperti halnya dengan akta otentik yaitu apabila dilakukan legalisasi oleh notaris (waarmerking) akta otentik maupun akta dibawah tangan harus ditandatangani oleh subjek hukum yang membuatnya, hal ini sebagimana yang ditentukan dalam pasal 1869 KUHPerdata yang menyatakan bahwa suatu akta yang tidak dapat diperlakukan sebagai akta otentik, baik karena tidak berwenang atau tidak cakapnya pejabat umum yang bersangkutan maupun karena cacat dalam bentuknya, mempunyai kekuatan sebagai tulisan dibawah tangan bila ditandatangani oleh para pihak. ${ }^{15}$

Penafsiran perjanjianJika terjadi sengketa antara para pihak dan atas sengketa tersebut tidak ada pengaturang yang jelas dalam perjanjian yang disepakati pada para pihak, bukan berarti perjanjian belum mengikat para pihak atau dengan sendirinya batal demi hukum. Karena pengadilan dapat mengisi kekosongan hukum tersebut melalui penafsiran untuk menemukan hukum yang berlaku bagi para pihak yang membuat perjanjian.

Kitab Undang-Undang Hukum Perdata mengatur hal ini dalam pasal 1343-1347 :Pasal 1343: Jika kata-kata suatu perjanjian dapat diberikan berbagai macam penafsiran, maka harus diselidiki maksud kedua belah pihak yang membuat perjanjian. Misalnya, apakah para pihak sesungguhnya bermaksud membuat perjanjian penitipan barang atau perjanjian sewa menyewa. Dalam perjanjian penitipan barang, pihak yang menerima titipan bertanggung jawab terhadap kehilangan barang yang dititipkan sedangkan dalam sewa menyewa pihak yang menyewa tempat tidak bertanggung jawab atas barang milik penyewa.

Dalam KUHPerdata buku III tentang akibat hukum perjanjian, pasal 1338 berbunyi “ semua perjanjian yang dibuat secarah sah berlaku sebagai undang-undang bagi mereka yang membuatnya. Perjanjian-perjanjian itu tidak dapat ditarik kembali selain dengan sepakat kedua belah pihak, atau karena alasan-alasan yang oleh undang-undang dinyatakan cukup untuk itu. Perjanjian-perjanjian harus dilaksanakan dengan itikad baik. $^{16}$

\section{B. Pengertian Umum tentang Fidusia}

Jaminan Fidusia telah digunakan di Indonesia sejak zaman penjajahan Belanda sebagai suatu bentuk jaminan yang lahir dari yurisprudensi, yang semula berasal dari zaman Romawi. Di negeri asalnya tersebut, selain bentuk jaminan juga sebagai lembaga titipan. Dalam hukum Romawi lembaga fidusia ini dikenal dengan nama Fiducia cum creditore

\footnotetext{
${ }^{15}$ Kartini Muljadi \& Gunawan Widjaja. Perikatan yang Lahir dari Perjanjian (Jakarta: Rajawali Pers 2014) hlm. Ibid hlm 87-89

${ }^{16}$ Ahmadi Miru, Sakka Pati, 2008, Hukum Perikatan Penjelasan Makna Pasal 1233 Sampai 1456 $B W$, Rajawali Pers, Jakarta, hlm.78
} 
contrata (artinya janji kepercayaan yang dibuat kreditor). Isi janji yang dibuat pleh debitor dengan kreditornya adalah debitur akan mengalihkan kepemilikan atas suatu benda sebagai jaminan utangnya kesepakatan bahwa debitor tetap akan menguasai secara fisik benda tersebut dan kreditor akan mengalihkan kembali kepemilikan tersebut kepada debitor bilamana utangnya sudah dibayar lunas. ${ }^{17}$

Fidusia ini berasal dari kata Fiduciair atau Fides, yang artinya kepercayaan, yakni kepercayaan hak milik atas benda secara kepercayaan sebagai jaminan (agunan) bagi pelunasan piutang kreditor. Penyerahan hak milik atas benda ini dimaksudnya hanya sebagai agunan bagi pelunasan utang tertentu, dimana memberikan kedudukan yang diutamakan kepada penerima fidusia (kreditor) terhadap kreditor lainnya. ${ }^{18}$

Senada dengan pengertian di atas, ketentuan dalam pasal 1 angka 1 Undang-Undang Nomor 42 Tahun 1999 tentang Jaminan Fidusia menyatakan "Fidusia adalah pengalihan hak kepemilikan suatu benda atas dasar kepercayaan dengan ketentuan bahwa benda yang hak kepemilikannya diahlikan tersebut tetap dalam penguasaan pemilik benda". Dari rumusan ini, dapat diketahui unsur-unsur fidusia itu, yaitu :

1. Pengalihan hak kepemilikan suatu benda,

2. Dilakukan atas dasar kepercayaan.

3. Kebendaannya tetap dalam penguasaan pemilik benda. ${ }^{19}$

Fidusia dikenal dengan beberapa asas yakni :

\section{Asas Droit De Suite}

Setiap Hak kebendaan memiliki sifat "droit de suite" yaitu suatu hak yang selalu mengikuti bendanya ditangan siapapun benda tersebut berada, droit de suite atau hak yang selalu mengikuti bendanya merupakan suatu hak kebendaan yang dianut dalam KUHPerdata. ${ }^{20}$ Sifat "droit de suite" terkandung dalam pasal 7 UU Hak Tanggungan yang menjelaskas "Hak Tanggungan tetap mengikuti objeknya dalam tangan siapapun objek tersebut berada, ${ }^{, 21}$ sedangkan dalam Lembaga Jaminan Fidusia sebagaimana diatur dalam pasal 20 UU Fidusia menyebutkan "jaminan fidusia tetap mengikuti benda yang menjadi objek jaminan fidusia dalam tangan siapapun benda tersebut berada, kecuali pengalihan atas benda persediaan yang menjadi objek Jaminan Fidusia” Pasal 20 ini menjelaskan bahwa ketentuan ini telah mencakup prinsip "droit de suite" yang telah merupakan bagian dari peraturan perundang-undangan Indonesia dalam kaitannya dengan hak mutlak atas kebendaan. ${ }^{22}$

${ }^{17}$ Rachmadi Usman, 2016. Hukum Jaminan Keperdataan, Sinar Grafika, Jakarta. Hlm.150-151

${ }^{18}$ Ibid, hlm. 151

${ }^{19}$ Ibid, hlm. 152

${ }^{20}$ DY. Witanto,2015. Hukum Jaminan Fidusia Dalam Perjanjian Pembiayaan Dan Konsumen. Mandar maju. Bandung, hlm.112

${ }^{21}$ Ibid, hlm. 112

${ }^{22}$ Subandi Martha,2016, Undang-Undang Jaminan Fidusia Nomor 42 tahun 1999 dilengkapi dengan peraturan pelaksaannya plus petunjuk, Tatanusa.jakarta.hlm 13 


\section{Asas Droit De Preference}

Setiap kreditur pemegang jaminan kebendaan pada umumnya selalu memiliki hak untuk mendahului, atau memiliki kedudukan yang didahulukan dari krediturkreditur lainnya. Ketentuan ini sebagai suatu pengecualian atau pengkhususan dari ketentuan pasal 1131KUHPerdata yang mengatur tentang jaminan umum. Pengecualian tersebut dapat kita temukan pada pasal 1133 KUHPerdata yang berbunyi "hak untuk didahulukan diantara orang-orang berpiutang terbit dari hak istimewa dari Gadai dan dari Hipotek" sedangkan hak istimewa menurut pasal 1134 ayat (1) KUHPerdata ialah suatu hak yang oleh undang-undang diberikan kepada seorang yang berpiutang sehingga kedudukannya lebih tinggi dari pada orang berpiutang lainnya semata-mata berdasarkan sifat piutangnya. ${ }^{23}$

Maksud dari kedudukan yang diutamakan kepada kreditur tertentu terhadap kreditur lain adalah jika debitur cidera janji (wanprestasi), maka kreditur pemegang jaminan kebendaan (kreditur Gadai, Hipotek, Hak Tanggungan dan Fidusia) berhak menjual melalui pelelangan umum objek yang dijadikan jaminan menurut peraturan perundang-undangan yang berlaku dengan hak mendahului dari kreditur-kreditur yang lainnya. ${ }^{24}$

Pasal 27 UU Fidusia menjelaskan tentang Hak Mendahului adalah sebagai berikut :

1) Penerima Fidusia memiliki hak yang didahulukan terhadap kreditur lainnya.

2) Hak yang didahulukan sebagaimana dimaksud dalam ayat (1) adalah hak Penerima Fidusia untuk mengambil pelunasan piutangnya atas hasil eksekusi Benda yang menjadi objek Jaminan Fidusia.

3) Hak yang didahulukan dari Penerima Fidusia tidak hapus karena adanya kepailitan dan atau likuidasi Pemberi Fidusia. ${ }^{25}$

3. Asas Publisitas

Asas Publisitas artinya bahwa setiap pembebanan jaminan dilakukan secara terbuka dan tegas, tidak dilakukan secara diam-diam dan tersembunyi, menurut asas publisitas ini setiap pembebanan jaminan wajib didaftarkan di tempat dimana undang-undang telah menunjuk tempat pendaftaran tersebut. Semua jaminan kebendaan mensyaratkan adanya pendaftaran kecuali pada jaminan Gadai, karena Gadai secara langsung benda jaminannya diserahkan kepada pihak kreditur, sehingga asas publisitas pada jaminan Gadai dilakukan dengan cara menyerahkan bendanya. ${ }^{26}$

Dalam Jaminan Fidusia ketentuan tentang pendaftaran diatur dalam Pasal 11 ayat (1) UU Fidusia yang menyebutkan bahwa "benda yang dibebani dengan jaminan fidusia wajid didaftarkan" dan pada pasal 12 UU Fidusia disebutkan bahwa

${ }^{23}$ DY. Witanto,2015. Hukum Jaminan Fidusia Dalam Perjanjian Pembiayaan Dan Konsumen. Mandar maju. Bandung,hlm.114

${ }^{24}$ Ibid, hlm.114-115

${ }^{25}$ Subandi Martha,2016, Undang-Undang Jaminan Fidusia Nomor 42 tahun 1999 dilengkapi dengan peraturan pelaksaannya plus petunjuk, Tatanusa.jakarta.hlm.17

${ }^{26}$ DY. Witanto,2015. Hukum Jaminan Fidusia Dalam Perjanjian Pembiayaan Dan Konsumen. Mandar maju. Bandung,hlm.117 
pendaftaran tersebut dilakukan di kantor Pendaftaran Fidusia pada Departemen Kehakiman yang saat ini menjadi Departemen Hukum dan HAM. ${ }^{27}$ Didalam Perjanjian antara kreditur dan debitur, harus ada juga perjanjian tambahan, yakni perjanjian Fidusia, dan perjanjian Fidusia ini perlu di daftarkan untuk menjadi akta Fidusia.

Berdasarkan Pasal 12 ayat (1) UU Fidusia menyebutkan bahwa "pendaftaran Jaminan Fidusia sebagaimana dimaksud dalam Pasal 11 ayat (1) dilakukan di Kantor Pendaftaran Fidusia”. Sedangkan menurut penjelasan Pasal 12 disebutkan bahwa "Kantor Pendaftaran Fidusia merupakan bagian dalam lingkungan Departeman Kehakiman (saat ini Departeman Hukum dan HAM) dan bukan Institusi yang mandiri atau unit pelaksanaan teknis. Kantor Pendaftaran Fidusia didirikan untuk pertama kali di Jakarta dan secara bertahap sesuai keperluan di Ibu Kota Propinsi diseluruh wilayah Republik Indonesia"28

Jika dikaji dari sifat sebuah jaminan, maka undang-undang menentukan proses pendaftaran Fidusia sebagai bentuk kewajiban merupakan keanehan, karena sebagaimana asas yang berlaku umum, sebuah jaminan itu selalu diatur dalam bentuk hak bukan kewajiban, artinya pihak kreditur boleh memilih untuk mendaftarkannya ataupun tidak karena jika jaminan tersebut tidak didaftarkan pada akhirnya yang akan rugi adalah pihak kreditur sendiri, namun dengan ditentukannya pendaftaran tersebut menjadi sebuah kewajiban, maka mau tidak kreditur harus melakukan pendaftaran tersebut, meskipun dari segi manfaat proses pendaftaran itu akan menentukan kedudukan yang jauh lebih baik bagi pihak kreditur. ${ }^{29}$

Pasal 13 ayat (2) UU Fidusia menyebutkan bahwa pernyataan pendaftaran antara lain memuat :

1. Identitas pihak Pemberi dan Penerima Fidusia

2. Tanggal, nomor akta Jaminan Fidusia, nama dan tempat kedudukan notaris yang membuat Akta Jaminan Fidusia

3. Data perjanjian pokok yang dijamin Fidusia

4. Uraian mengani benda yang menjadin objek Jaminan Fidusia

5. Nilai penjaminan

6. Nilai benda yang menjadi objek Jaminan Fidusia

\section{Pengertian Perjanjian Pembiayaan Konsumen.}

Pembiayan Konsumen bahasa Inggris disebut istilah 'consumer finance".Pembiayaan konsumen hakikat sama saja dengan kredit konsumen (consumen kredit) perbedaannya hanya terletak pada lembaga yang membiayainya, sedangkan kredit konsumen biaya diberikan oleh Bank. Pembiayaan konsumen biaya diberikan oleh perusahaan pembiayaan (financing company), Pembiayan konsumen sebagaimana diatur dalam Keppres No 61 tahun 1988 jo pasal 1 angka 6 dan keputusan Menteri KeuanganNo.1251/KMK.013/1988 pasal 1 huruf p kegiatan

\footnotetext{
${ }^{27}$ Ibid, hlm. 118

${ }^{28} \mathrm{Ibid}$, , hlm. 174

${ }^{29}$ Ibid, hlm.174-175
} 
pembiayaan dalam bentuk dana untuk pengadaan barang berdasarkan kebutuhan konsumen dengan sistim pembayaran angsuran- angsuran atau berkala oleh konsumen.

Dalam Peraturan Menteri Keuangan Republik Indonesia No. 130/PMK/010/2012 dosebutkan bahwa perusahaan pembiayaan yang melakukan pembiayaan konsumen untuk kendaraan bermotor dengan pembebanan jaminan fidusia wajib didaftarkan jaminan fidusia tersebut pada kantor jaminan fidusia paling lambat 30 (tiga puluh) hari kalender terhitung sejak tanggal perjanjian pembiayaan konsumen. ${ }^{30}$ Menurut pasal 1 ( 6 ) Kepperes No 61 tahun 1988 tentang lembaga konsumen adalah pembiayaan pengadaan barang untuk kebutuhan konsumen dengan sistem pembayaran angsuran atau bekala.

Menurut Abdulkadir Muhammad dan Rilda Murniati merincikan unsur yang terkandung dalam pengetian pembiayaan konsumen yaitu : ${ }^{31}$

1. Subjek adalah pihak-pihak yang terkait dalam hubugan hukum pembiyaan konsumen yaitu perusahan konsumen (kreditor) konsumen ( debitor) dan penyedia barang ( supplier).

2. Objek adalah barang bergerak keperluan konsumen yang akan dipakai untuk keperluan hidup dan keperluan rumahtangga.

3. Perjanjian yaitu perbuatan persetujuan pembiayaan yang diadakan antara perusahaan pembiayan konsumen dan konsumen, serta jual beli antara pemasok dan konsumen,perjanjian didukung oleh dokumen-dokumen.

4. Hubungan antara hak dan kewajiban yaitu perusahan pembiayaayn konsumen wajib membiayai harga pembelian barang yang diperlukan konsumen dan membayar secara angsuran kepada perusahaan pembiayan konsumen dan wajib menyerahkan barang kepada konsumen.

5. Jaminan yaitu terdiri dari atas jaminan utama,pokok,tambahan.jaminan utama berupa kepercayaan terhadap konsumen ( debitor). jaminan pokok secara fidusia berupa barang yang dibiayai oleh perusahaan pembiayaan konsumen ( fiduciary transfer of ownweship) sampai angsuran terakhir dilunasi,adapun jaminan tambahan berupa pengakuan hutang ( promissory notes) dari konsumen

Perjanjian Pembiayaan pada umumnya dibuat dalam bentuk perjanjian baku atau juga disebut perjanjian standar, yaitu sebuah perjanjian yang dirumuskan oleh salah satu pihak (Pihak Lembaga Pembiayaan) dan pihak yang lain (konsumen) cukup sekedar mengakseptasi ketentuan-ketentuan yang tercantum dalam klausula perjanjian kepadanya dengan cara menandatangani akta perjanjian tersebut atau menolaknya. Model perjanjian baku yang dibuat dan ditandatangani oleh para pihak sering menimbulkan masalah jika isi perjanjian tersebut sebelumnya tidak dibaca atau dipahami, sehingga pada saat terjadi sengketa, salah satu pihak yang tentunya pihak debitur (konsumen) merasa tertipu dengan model perjanjian yang dianggapnya

\footnotetext{
${ }^{30}$ Yuziral,2011. Aspek Pidana Jaminan Fidusia, Surabaya. Media Nusa creative, hlm, 89-90

31 AbdulkadirMuhammad dan Rilda Murniati, 2000. segi hukum lembaga konsumen dan pembiayaan,Bandung: citra Aditya Bakti,hal 246
} 
menjerat, padahal ia sendiri telah lalai untuk membaca dan memahami terlebih dahulu isi dan kandungan yang ada dalam akta perjanjian tersebut. ${ }^{32}$

Perjanjian Pembiayaan Konsumen merupakan sebuah perjanjian timbal balik dimana salah satu pihak (lembaga pembiayaan) memberikan prestasi dalam bentuk pembiayaan (pembayaran dana) untuk pengadaan barang-barang tertentu yang dibutuhkan oleh pihak lain (konsumen) dengan timbal balik prestasi berupa pembayaran cicilan atas senilai pembiayaan yang diberikan berikut bunga dan ongkos-ongkos lainnya. ${ }^{33}$ Meskipun perjanjian pembiayaan konsumen tidak pernah dikenal dalam KUHPerdata, namun dengan mendasari pada asas kebebasan berkontrak sebagaimana diatur ketentuan Pasal 1338 KUHPerdata, maka parah pihak boleh membuat dan menentukan sendiri bentuk dan jenis perjanjian sebagaimana ditentukan dalam Pasal 1320 KUH Perdata, sedangkan perjanjian yang dibuat secara sah demi hukum akan mengikat para pihak sebagaimana undang-undang. ${ }^{34}$

Pasal 1338 KUHPerdata menyebutkan bahwa "semua persetujuan yang dibuat secara sah berlaku sebagai undang-undang bagi mereka yang membuatnya." Frasa "sebagai undang-undang bagi mereka yang membuatnya" memberikan makna bahwa perjanjian yang dibuat secara sah memiliki kekuatan mengikat yang sama dengan kekuatan mengikatnya undang-undang yang dibuat oleh penguasa, namun perlu di ingat bahwa kedudukan tersebut hanya ditujukan bagi para pihak yang membuat perjanjian saja, artinya meskipun perjanjian dipersamakan daya mengikatnya dengan undang-undang bukan berarti bahwa perjanjian itu memiliki kedudukan seperti undang-undang yang dapat berlaku secara umum. Makna dari "kekuatan mengikatnya sebagaimana undang-undang" semata-mata terletak pada hak untuk menuntut pemenuhan prestasi dan anti kerugian di hadapan pengadilan Negara seperti halnya jika orang telah melanggar undang-undang. ${ }^{35}$

\section{Pengertian Wanprestasi pada umumnya}

Wanprestasi mempunyai hubungan yang sangat erat dengan somasi wanprestasi adalah tidak memenuhi atau lalai melaksanakan kewajiban. Suatu perjnjin dapat dilaksnakan dengan baik apabila para pihak telah memenuhi syarat yang telah diperjanjiankan walaupun demikian pada kenyataan sering dijumpi bahwa pelaksanan dari suatu perjanjian tidak dapat berjalan dengan baik karena salah satu pihak karena wanprestasi. Kelalaian atau kealpan dalam hukum perdata si berhutang wajib melakukan sesuatu atau tidak melakukan sesuatu atau tidak memenuhi, menepati kewajiban yang telah diperjanjikan lazim dikatakan sebagai wanprestasi yang dikenal dengan ingkar janji.

\footnotetext{
${ }^{32}$ Ibid, ,hlm.119

${ }^{33} \mathrm{Ibid}, \mathrm{hlm} .119$

${ }^{34}$ Ibid, hlm. 120

${ }^{35} \mathrm{Ibid}$, hlm. 120
} 
Menurut Munir Fuady, Wanprestasi adalah ${ }^{36}$ tidak dilaksanakan prestasi atau kewajiban sebagaimanan mestinya yang dibebankan oleh kontrak kepada pihak-pihak tertentu seperti yang disebutkan dalam kontrak yang bersangkutan.

Wanprestasi (kelalaian atau kelapaan) seorang debitor dapat berupa empat macam :

a. Tidak melakukan apa yang disanggupi akan dilakukanya

b. Melaksanakan apa yang dijanjikannya, tetapi tidak sebagimana dijanjikan

c. Melakukan apa yang dijanjikanya tetapi terlambat

d. Melakukan sesuatu yang menurut perjanjian tidak boleh dilakukanya

\section{METODE PENELITIAN}

Tipe penelitian yang digunakan yaitu tipe penelitian Yuridis Empiris. Tipe penelitian Yuridis Empiris yakni, artinya pada prinsipnya merupakan penelitin hukum bersifat nyata, pendekatan empiris dimaksud sebagai usaha pendekatan maka yang diteliti dengan sifat hukum yang nyata atau sesuai dengan kenyataan hidup dalam masyarakat. ${ }^{37}$

Lokasi penelitian berada di Kota Ternate, yaitu pada suatu Perusahaan Pembiayaan Konsumen, PT. Mitra Dana Top Finance.PT. Mitra Dana Top Finance Kota Ternate adalah satu bentuk lembaga pembiayaan yang ada di Kota Ternate yang fokus dibidang Pembiayaan kepemilikan kendaraan bermotor, alas an bahwa hak dan kewajian par pihak dalam perjanjian pembiayaan jaminan fidusia di PT MDTF Kota Ternate merupakan salah satu peruahan yang banyak dipercaya oleh masyarakat.

Jenis dan sumber data yang gunakan dalam penelitian ini adalah sebagai berikut:

\section{Data Primer}

Yaitu data yang diperoleh secara langsung dari masyarakat yang merupakan keterangan yang diperoleh dari sumber data langsung atas keterangan yang jelas dan nyata.

\section{Data sekunder}

Yaitu data yang diperoleh langsung melalui studi kepustakaan dengan cara mencari konsep-konsep, teori-teori, asas-asas, dan pendapat-pendapat para ahli yang berhubungan erat dengan masalah yang diambil penulis.

Teknik pengumpulan data yang dilakukan oleh penulis ini adalah sebagai berikut:

1. Wawancara,yaitu pengumpulan data yang diperoleh secara langsung dari lokasi penelitian yang berupa hasil pengumpulan data dari wawancara dan bertatap muka secara langsung. Adapun yang menjadi responden yaitu : Manager atau Ketua Cabang PT. Mitra Dana Top Finance, karyawan PT. Mitra Dana Top Finance dan Konsumen atau Masyarakat.

2. Penelitian Kepustakaan,yaitu pengumpulan data yang berupa sejumlah data dari masyarakat, notaris dan melalui buku -buku, atau lainnya yang berhubungan langsung dengan pembahasan penelitian yang penulis bahas saat ini.

\footnotetext{
${ }^{36}$ Munir Fuady, Hukum tentang pembiayaan dalam teori dan praktik,Banung,citr Bakhti,1995,hal 40

37 Hilman Hadi Kusumn,Metode pembutn kerts kerj/skripsi ilmu hukm,Bandung mandr maju,1995.hal 61
} 
Penelitian ini menggunakan analisis data deskriptif kualitatif, yaitu metode dimana data yang dperoleh dan disusun secara sistimatis dan pendekatan diskriptif tentang tinjn hukum pelaksanan pembiayaan konsumen kendaraan roda dua di PT Mitra Dana Top Finance kota ternate.

\section{PEMBAHASAN}

\section{A. Hak dan Kewajiban Perjanjian Pembiayaan di PT. Mitra Dana Top Finance Kota Ternate.}

Sebelum pelaksanaan perjanjian pembiayaam di PT.Mitra Dana Top Finance Kota Ternate antara para pihak yaitu kreditor dan debitor dinyatakan secara sah melengkapai persyartaan untuk mengajukan kredit diserahkan kepada debitor berupa foto copy KTP, Foto copy kartu keluarga dan lain-lain sebagaimana persyaratan yang diberikan oleh perusaham pembiyaan. Setelah semua persyaratan telah terpenuhi PT. Mitra Dana Top Finance melakukan survei dan analisis setiap permohon. Pelaksanaan perjanjian pembiayaan tidak semua dapat berjalan sebagaimana mestinya, hal ini terjadi pada PT. Mitra Dana Top Finance Kota Ternate jumlah nasabah mengalami kenaikan maupun penurunan sebagaimana disajikan pada table di bawah ini :

Tabel. 4.1 Perkembangan Nasabah di PT. Mitra Dana Top Finance kota Ternate Selama 4 tahun 2015 sampai 2018.

\begin{tabular}{|c|c|c|c|}
\hline NO & Tahun & Jumlah Nasabah & Persentase ( \% ) \\
\hline 1 & 2015 & 1100 & 26 \\
\hline 2 & 2016 & 828 & 20 \\
\hline 3 & 2017 & 1493 & 35 \\
\hline 4 & 2018 & 793 & 19 \\
\hline \multicolumn{2}{|c|}{ Jumlah Nabasah } & 4214 & 100 \\
\hline
\end{tabular}

Sumber : PT. Mitra Dana Top Finance Kota Ternate, diolah ,2018

Perkembangan Nasabah di PT. Mitra Dana Top Finance, seiring berjalannya waktu, nasabahnya dari tahun ketahun mengalami kenaikan serta penurunan, terjadi pada tahun 2015 jumlah nasabah 1100 (26\%), Tahun 2016 jumlah nasabah 828 (20\%), Tahun 2017 jumlah nasabah 1493 (35\%), dan di tahun 2018 jumlah nasabah 793 (19\%) ini terjadi kenaikan serta penurunan nasabah sebagaimana diuraikan di atas ini, namun masih bisa dikatakan bahwa banyak masyarakat yang menggunakan jasa lembaga pembiayaan dan kepercayaan masyarakat sangat tinggi terhadap lembaga pembiayaan di PT. Mitra Dana Top Finance. Nasabah yang telah melaksanan perjanjian telah mengisi perjanjian sebagaimana terdapat klausula Hak dan kewajiban.

Isi perjanjian di PT.Mitra Dana Top Finance klausula tentang hak dan kewajiban ${ }^{38}$ bahwa hak dan kewajiban para pihak telah termuat dalam klausul sebagi berikut :

\footnotetext{
${ }^{38}$ Klausul perjanji di PT.MDTF Kota Ternate
} 


\section{Hak dan Kewajiban Debitor :}

Debitor Berhak menerima objek jaminan, Debitor berkewajiban menyerahkan atau membayar sejumlah uang sebagai uang muka, Debitor berkewajiban membayar angsuran setiap bulannya, Debitor tidak diperbolehkan menggunakan objek jaminan tersebut untuk melakukan perbuatan melawan hokum atau melanggar peraturan perundang-undangan, Debitor berkewajiban melunasi seluruh hutang kepada kreditor, dan debitor berkewajiban menyerahkan objek jaminan kepada kreditor apabila debitor lalai atau melakukan wanprestasi.

\section{Hak dan Kewajiban Kreditor :}

Kreditor berkewajiban menyediakan objek jaminan yang diinginkan oleh debitor, kreditor berhak menerima uang angsuran dari debitor setiap bulannya, Kreditor berhak sewaktuwaktu mengubah suku bunga dari objek jaminan, kreditor berhak menarik atau mengeksekusi objek jaminan apabila debitor melakukan wanprestasi. ${ }^{39}$ Berdasarkan wawancara kepala cabang. Hak dan Kewajiban kreditor adalah menyediakan barang berupa motor, menagih uang angsuran dari debitor, dan menarik barang jaminan apabila debitor melakukan wanprestasi. Hak dan Kewajiban dari debitor adalah menerima barang jaminan untuk dipergunakan, membayar angsuran barang jaminan tersebut, melunasi secara keseluruhan harga barang jaminan yang diperjanjikan, dan debitor harus menyerahkan barang jaminan apabila tidak mampu lagi untuk membayar barang yang diperjanjikan..

Menurut salah seorang nasabah dari PT. Mitra Dana Top Finance, menjelaskan bahwa :

Hak dan Kewajibannya adalah Menerima objek jaminan dari PT. Mitra Dana Top Finance, melunasi atau membayar angsuran kepada PT. Mitra Dana Top Finance, dan Menyerahkan kembali objek jaminan apabila terjadi kelalaian atau wanprestasi, untuk Kreditor, Hak dan Kewajibannya adalah menyediakan objek jaminan yang di inginkan debiotor, Menerima angsuran atau penulasan barang dari debitor, dan mengambil objek jaminan apabila debitor melakukan kelalaian. ${ }^{40}$

Berdasarkan uraian di atas pelaksanaan hak dan kewajiban yang di simpangi salah satu pihak, walaupun kedua pihak telah mengetahui hak dan kewajiban masing-masing akan tetapi masih terjadi kelalaian khususnya pada pihak debitor yang tidak melaksanakan prestasinya, hal ini sebagaimana asas kebebasan berkontrak yang mengartikan bahwa perjanjian yang telah dibuat tersebut mengikat bagi mereka yang membuatnya seperti halnya undang-undang.

Pasal 1239 Kitab Undang-Undang Hukum Perdata disebutkan :"Tiap-tiap perikatan berbuat sesuatu, atau tidak berbuat sesuatu, apabila yang berhutang tidak memenuhi kewajibannya, mendapatkan penyelesaian dalam kewajiban memberikan penggantian biaya, rugi, dan bunga. Pemenuhan Hak dan kewajiban dalam hukum perjanjian di jamin oleh Undang-Undang, karena pengaturan hak dan kewajiban kreditor dan debitor dalam perjanjian menjamin sejumlah asas yang menjadi prinsip perjanjian secara umum

\footnotetext{
${ }^{39}$ Wawancara penulis tanggal 11 januari 2019

${ }^{40}$ Wawanvara penulis tanggal 14 januari 2019
} 
dicantumkan dalam perjanjian. Kebebasan berkontrak didasarkan pada asumsi bahwa para pihak dalam berkontrak memiliki posisi tawar (bargaining position) yang seimbang, tetapi dalam kenyataannya para pihak tidak selalu memiliki posisi tawar yang seimbang. ${ }^{41}$

Berdasakan hasil penelitian bahwa bentuk perjanjain yang dilakukan oleh PT. Mitra Dana Top Finance Kota Ternate berbentuk Tertulis oleh karena itu semua perjanjian yang dilakukan oleh nasabah telah terpenuhi Hak dan kewajiban. Perjanjian Baku yang dibuat oleh PT. Mitra Dana Top Finance dalam klausulnya diatas tidak seimbang jika dibaca seacara seksama dan ini dapat memperngaruhi hak dan kewajiban antara kreditor dan debitor yang mana, banyak yang merugikan debitor. Ketidakseimbangannya dapat dilihat dalam salah satu pasal dalam perjanjian baku PT. Mitra Dana Top Finance yaitu pada pasal 2 ayat (2): Pihak Pertama berhak sewaktu-waktu merubah suku bunga dan provisi tersebut sesuai dengan keadaan tanpa memerlukan persetujuan terlebih dahulu dari Pihak Kedua dan juga tanpa pemberitahuan terlebih dahulu kepada Pihak Kedua, dan Pihak kedua dengan ini berjanji akan selalu menerima sepenuhnya perubahan tersebut. Pasal ini sangat merugikan debitor, sebab suku bunga dari barang yang diperjanjikan awal dapat berubah sewaktu-waktu tanpa persetujuan dari pihak debitor, suku bunga dari barang yang diperjanjikan dapat merubah harga barang secara keseluruhan, dan ini pasti tidak akan sesuai dengan harga barang yang diperjanjikan dari awal.

Walaupun demikian, Hak dan Kewajiban debitor masih saja di rugikan sebab dalam isi klausulnya PT. Mitra Data Top Finance belum di buat seimbang melainkan memberatkan salah satu pihak, dalam hal ini debitor, mulai dari suku bunga yang diubah tanpa sepengetahuan debitor, sampai pada Penarikan objek Jaminan yang tidak sesuai dengan peraturan yang berlaku.

\section{B. Eksekusi Barang Jaminan terjadi kredit macet di PT. Mitra Dana Top Finance}

Barang yang menjadi objek Jaminan Fidusia atas kekuasaan sendiri. Hak yang dimiliki Kreditor untuk menjual atas kekuasaan sendiri benda yang menjadi objek jaminan fidusia merupakan satu ciri Jaminan Fidusia yang memberikan kemudahan dalam melaksanakan eksekusinya apabila debitur cidera janji. Hak menjual yang dimiliki Kreditor untuk menjual atas kekuasaan sendiri atas benda yang menjadi objek jaminan fidusia disebut Parate Eksekusi. Permasalahan hak Kreditor untuk menjual atas kekuasaan sendiri terhadap benda yang menjadi objek Jaminan Fidusia. Perbuatan hukum yang dilakukan oleh debitor apabila melakukan wanprestasi dalam perjanjian ini maka timbul akibat hukum.

Wanpretasi yang terjadi PT. Mitra Dana Top Finance Kota Ternate Menarik objek jaminan atau mengeksekusi objek jaminan apabila debitor lalai dalam melaksanakan kewajibannya atau melakukan suatu wanprestasi, hal ini terbukti dari hasil penelitian terdapat wanprestasi yang di lakukan oleh nasabah sebagaimana di uraikan pada table berikut :

41 Agus Yudha Hernoko, 2010. HUkum Perjanjian Asas Proporsionalitas dalam Kontrak Komersial. Prenadamedia Group. Jakarta, hlm. 111 
Tabel 4.2 : Jumlah Nasabah yang wanprestasi di P.T.Mitra Dana Top Finance Kota Ternate Tahun 2015 -2018

\begin{tabular}{|c|c|c|c|}
\hline $\mathrm{NO}$ & Tahun & Wanprestasi & Persentase ( \%) \\
\hline 1 & 2015 & 71 & 29 \\
\hline 2 & 2016 & 93 & 37 \\
\hline 3 & 2017 & 27 & 11 \\
\hline 4 & 2018 & 56 & 23 \\
\hline \multicolumn{2}{|c|}{ Jumlah } & 247 & 100 \\
\hline
\end{tabular}

Sumber : PT. Mitra Dana Top Finance, Kota Ternate, diolah, 2018

Uraian table di atas bahwa jumlah nasabah dari tahun ketahun mengalami peningkatan serta penurun yang terjadi di tahun 2015 sejumlah 71 (29\%), tahun 2016 sejumlah 93 (37\%), tahun 2017 sejumlah 27 (11\%), dan di tahun 2018 sejumlah 56 (23\%).

Peningkatan wanprestasi di PT. Mitra Dana Top Finance Kota Ternate Kredit macet bisa terjadi karena beberapa faktor diantaranya situasi ekonomi debitor yang lagi sulit sehingga menghambat debitor untuk membayar angsuran secara berkala dan tepat waktu sesuai diperjanjikan. Kerugian yang dialami oleh PT. Mitra Dana Top Finance Kota Ternate ini menyebabkan mereka mengambil langkah-langkah dalam memulihkan kerugiannya, namun banyak hambatan yang di alami dalam proses itu berlangsung oleh karena itu kontrak yang diperjanjikan antara kedua pihak harus memenuhi syarat-syarat dan ketentuan untuk meminimalisir masalah yang terjadi kedepannya.

Menurut Karyawan PT. Mitra Dana Top Finance, ibu Eti bahwa PT. Mitra Dana Top Finance dalam hal Eksekusi barang Jaminan karena suatu hal yang di lakukan debitor berupa wanprestasi, masih memakai Surat Peringat Pertama (SP 1), Surat Peringat Kedua (SP 2) dan apabila debitor tidak mengindahkan maka dikeluarkanlah Surat Peringat Ketiga (SP 3), SP 3 ini memuat tentang Surat Kuasa untuk mengambil Barang jaminan dari tangan Debitor. ${ }^{42}$ Nasabah PT.Mitra Dana Top Finance ibu Ani, mengatakan bahwa cara mereka menarik barang atau mengeksekusi barang dengan cara membuat surat peringatan, yaitu SP 1, lalu SP 2, dan kemudian melakukan SP 3, SP 3 itu dalam bentuk surat kuasa, sehingga kendaraan motor saya diambil langsung oleh mereka. ${ }^{43}$

Berdasarkan penjelasan di atas PT.Mitra Dana Top Finance dalam melakukan eksekusi terhadap jaminan fidusia karena hal ini tertuang dalam perjanjian yang dilakukan tertang perjanjian sebagai berikut : Pasal 10, bila pihak kedua melanggar/lalai/wanprestasi atau tidak mentaati ketentuan-ketentuan dalam perjanjian pembiayaan ini, maka pihak kedua memberikan ijin dan kuasa kepada pihak pertama untuk meminta penyerahan objek jaminan dari pihak kedua/pihak manapun dengan resiko menjadi tanggung jawab pihak kedua sepenuhnya.

${ }^{42}$ Wawancara penulis pada tanggal 17 Januari 2019

${ }^{43}$ Wawancara penulis dengan nasabah PT. Mitra Dana Top Finance tanggal 14 januari 2019 
Menurut hukum setiap penyelesaian eksekusi objek jaminan fidusia yang dilakukan seorang debitor karena wanprestasinya di Undang-Undang Fidusia dijelaskan tata cara eksekusi, cara yang pertama apabila kedua belah pihak sepakat, artinya baik debitor atau kreditor sepakat untuk menjual kendaraan tersebut dengan cara di iklankan ataupun di lelang, harga jualnya itu kemudian di bayarkan kepada kreditor apabila kurang akan di tambah oleh debitor apabila lebih maka kreditur wajib mengembalikannya kepada debitur, atau dengan cara debitur melakukan penjualan dan melaporkan hasil penjualan tersebut kepada kreditor, atau bias juga sebaliknya debitor dengan sukarela menyerahkan kepada kreditor untuk dijual oleh kreditor dan kreditor melaporkan hasil penjualannya kepada debitor. Cara yang kedua adalah apabila debitor sebagai pemegang kendaraan bermotor menolak untuk menyerahkan kendaraannya. Maka, kreditor tidak dapat seketika itu melakukan eksekusi objek jaminan tersebut. Karena ketentuan daripada undangundang fidusia mewajibkan ketika penarikan terhadap sebuah objek barang jaminan harus di damping oleh aparat penegak hukum.

Pasal 29 Undang-Undang Fidusia memberikan berbagai cara untuk melakukan eksekusi terhadap benda yang menjadi obyek Jaminan Fidusia dengan cara sebagai berikut:

Berdasarkan Sertifikat Jaminan Fidusia yang mempunyai kekuatan
eksekutorial yang sama dengan putusan pengadilan yang telah
memperoleh kekuatan hukum tetap, Kreditur atas kekuasaannya sendiri
dapat menjual benda yang menjadi obyek Jaminan Fidusia kepada yang
berminat. Penjualan dapat dilakukan sendir oleh Kreditur tanpa bantuan
Kantor Lelang. Dalam Sertifikat Jaminan Fidusia yang diterbitkan kantor
Pendaftaran Fidusia dicantumkan kata-kata "Demi Keadilan Berdasarkan
Ketuhanan Yang Maha Esa". Sertifikat Jaminan Fidusia ini mempunyai
kekuatan eksekutorial yang sama dengan putusan pengadilan yang telah
$\begin{aligned} & \text { Dengan demikian berdasarkan Sertifikat Jaminan Fidusia tersebut bila } \\ & \text { debitur cidera janji, Kreditur sebagai Penerima Fidusia dapat menjual. }\end{aligned}$

Hasil Penelitan menunjukan terhadap salah satu nasabah yang objek barang jaminannya dieksekusi tanpa adanya akta jaminan fidusia, eksekusi yang dilakukan hanya memakai surat kuasa. Dan belum memakai akta jaminan fidusia.

Pasal 30 Undang-Undang Jaminan Fidusia mewajibkan pemberi fidusia untuk menyerahkan benda yang menjadi objek jaminan fidusia. Pelaksanaan eksekusi jaminan fidusia.Dengan demikian pelaksanaan titel eksekusi ( atas hak eksekusi) oleh penerima fidusia mengandung 2 (dua) syarat utama yakni:

a) Debitor atau Pemberi Fidusia cidera janji.

b) Ada sertifikat Jaminan Fidusia yang mencantumkan Demi Keadilan Berdasarkan Ketuhanan Yang Maha Esa.

Berdasarkan hasil Penelitian penulis yang terjadi PT.Mitra Dana Top Finance Kota Ternate dalam perjanjian pembiayaan dengan jaminan kredit tidak dibuat atau belum ada akta jaminan fidusia, ketika konsumen atau nasabah melakukan wanprestsi akibat krediat macet ( tidak bisa membayar angsuran) PT. Mitra Dana Top Finance mengalami kesulitan melakukan eksekusi hanya denga dibuat surat peringatan SP.1.SP.2 dan S.P.3. 
Praktek perkreditan selama ini, ada suatu kesulitan dari pihak Penerima Fidusia untuk melakukan eksekusi fidusia apabila pemberi Fidusia melakukan wanprestasi karena secara nyata benda-benda yang menjadi objek fidusia itu masih berada dalam penguasaan pemberi Fidusia atau debitor.

Masyarakat umum atau Nasabah PT.Mitra Dana Top Finance tidak mengetahui bahwa benda-benda yang dikuasai oleh pemberi Fidusia sudah dijadikan jaminan sebagai objek Fidusia, karena tidak adanya sistem pendaftaran yang diintrodusir oleh undang-undang ini yang mewajibkan pendaftaran objek jaminan Fidusia di Kantor Pendaftaran Fidusia sehingga barang-barang bergerak yang dikuasai Debitor tersebut dianggap milik mutlak Debitor akan tetapi pendaftaran Fidusia bisa dilakukan di Kantor Kementerian Hukum dan HAM disetiap wilayah, tanpa perlu mendaftarkan langsung di Kantor Kementerian Hukum dan HAM pusat, sehingga dengan begini lebih mudah untuk mendaftarkannya.

\section{PENUTUP}

Hak dan Kewajiban antara debitor dan kreditor telah dituangkan dalam klausul perjanjian, ini berarti klausul hak dan kewajibannya telah terpenuhi, namun klausul yang dibuat oleh PT. Mitra Dana Top Finance masih terdapat kalausul yang tidak seimbang dan masih merugikan salah satu pihak yaitu debitor. Wanprestasi yang di alami PT. Mitra Dana Top finance inimasih banyak, dan PT. Mitra Dana Top Finance dalam hal mengeksekusi barang hanya memakai SP. 1, SP. 2, dan SP. 3 (surat kuasa) untuk mengeksekusi objek jaminan di tangan debitor tanpa menggunakan akta jaminan Fidusia

\section{DAFTAR PUSTAKA}

Abdul Kadir Muhamad dan Rilda Muniarti, 2001. segi hukum lembaga keuangan dan pembiayaan. Citra Aditya Bakti. Bandng,

Agus Yudha Hernoko, 2010. Hukum Perjanjian Asas Proporsionalitas dalam kontrak Komersial. Prenadamedia Group. Jakarta

Ahmadi Miru dan Sakka Pati. 2008, Hukum Perikatan Penjelasan Makna Pasal 1233 Sampai 1456 BW, Rajawali. Jakarta

Celina Tri Siwi Kristiyanti, 2008, Hukum Perlindungan Konsumen. Sinar Grafika. Jakarta

D.Y, Witanto. 2015. Hukum Jaminan Fidusia dalam Perjanjian Pembiayaan Konsumen, Mandar maju. Bandung

Hilman Hadi Kusuma, 1995. Metode pembutan kertas kerja atau skrips ilmu hukum, Mandar Maju. Bandung

Kartini Muljadi \& Gunawan Widjaja. 2014. Perikatan yang Lahir dari Perjanjian. Rajawali. Jakarta

Khotibul Umam. 2010. Hukum Lembaga Pembiayaan, Pustaka Yustisia. Yogyakarta Munir Fuady, 1995. Hukum tentang Pembiayan dalam teori dan praktik. Citta Adiya Bakti. Bandung 
Rachmadi Usman. 2016. Hukum Jaminan Keperdataan. Sinar Grafika. Jakarta R. Subekti dan R. Tjitrosudibio. 1996. Kitab Undang Undang-Undang Hukum Perdata Burgerlijk Wetboek. Pradnya Paramita. Jakarta. , 1976. Hukum Perjanjian. PT Intermasa. Jakarta

Salim H.S, 2003, Hukum Kontrak Teori \& Tehnik Penyusunan Kontrak, Sinar Grafika, Jakarta

Simanjuntak, 2015, Hukum Perdata Indonesia, PT. Kharisma Putra utama, Jakarta,

Subandi Martha. 2016, Undang-Undang Jaminan Fidusia Nomor 42 tahun 1999 dilengkapi dengan peraturan pelaksaannya plus petunjuk, Tatanusa. jakarta

Sunaryo, 2008. Hukum Pembiayaan, Jakarta,Sinar Grafika

Sutarno, “ Aspek-Aspek Hukum Perkreditan pada Bank”, Bandung, 2005.

Yurizal, 2011. Aspek Pidana Jaminan Fidusia. Surabaya, Media Nusa Creative

Kitab Undang-Undang Hukum Perdata

Undang-Undang Nomor 42 Tahun 1999 Tentang Jaminan Fidusia

Undang-Undang Nomor 4 Tahun 1996 Tentang Hak Tanggungan

Keppres Nomor 61 Tahun 1988 Tentang Lembaga Pembiayaan Konsumen

JOM Fakultas Hukum Volume III Nomor 2, Oktober 2016

www.kostummerdeka.blogspot.com 